Journal of Extension Education

Vol. 28 No. 3, 2016

DOI:https://doi.org/10.26725/JEE.2016.3.28.5709-5718

\title{
Adoption of Indigenous Dairy Management Practices among Tribal Farm Women
}

\section{Chigasil M. Sangma ${ }^{1}$ and Santha Govind ${ }^{2}$}

\begin{abstract}
The study was conducted among the tribal farm women of West Garo Hills District of Meghalaya, India with the objective to determine the extent of adoption of indigenous dairy management practices. Proportionate random sampling was used in selection of 120 respondents. Practices having rationality for adoption of indigenous dairy management practices were collected and the data were analyzed using percentage analysis. The findings revealed that majority of the respondents adopted care and management of dry and pregnant cows. This was followed by adoption of other practices viz.., selection of breed and feeding, care during and after calving and milking technique
\end{abstract}

Keywords : Adoption, Indigenous Farm practices, Farm women, Dairy Management, Meghalaya

\section{INTRODUCTION}

Indigenous knowledge is usually adapted and specific to local ecological conditions and to community members' social and cultural beliefs. This knowledge can be simple or complex. It is not static but evolves in response to changing ecological, economic and socio-political circumstances based on the creativity and innovation of community members and as a result of the influence of other cultures and outside technologies.

Serote (2001) defined indigenous knowledge system as human experience, organized and ordered into accumulated knowledge with the objective to utilize it to achieve quality of life and to create a livable environment for both human and other forms of life. Indigenous knowledge is a set of perceptions, information and behaviour that guide local community members to use the land and natural resources. Indigenous knowledge is created and sustained by local community members as a means to meet their needs for food, shelter, health, spiritual and savings.

Tribal women constitute half of the work force among tribals in India. Tribal women have very little access to knowledge and skills on modern farm technologies and related resources. In spite of such shortcomings, tribal

1. P.G.Scholar and 2. Professor, Department of Agricultural Extension, Faculty of Agriculture, Annamalai Universiy, Annamalainagar 608 002, Tamil Nadu

Received : 03-08-2017; Accepted : 13-08-2017 
women have contributed lion's share to the family income through agriculture and allied sectors as compared to male counterparts. Meghalaya state is one of the states in India where indigenous knowledge is extensively used for livestock and other allied activity. West Garo Hills is one of the districts of Meghalaya where immense use of indigenous knowledge is widely seen in agricultural and allied activities.

Today many indigenous knowledge systems are at risk of becoming extinct because of rapidly changing natural environments and fast pacing economic, political and cultural changes on a global scale, practices vanish as they become appropriate for new challenges or because they adapt too slowly. Keeping this in view, an attempt has been made to find out the extent of adoption of indigenous dairy management practices among tribal farm women in West Garo Hills District of Meghalaya.

\section{METHODOLOGY}

West Garo Hills District in Meghalaya was selected for the study considering the availability of number of tribal women engaged in indigenous dairy management practices. Among the eight blocks, two blocks namely Selsella and Betasing were selected based on the maximum number of tribal farm women engaged in dairy management practices. A list of farm women owning minimum of 5 cattle in each village of the selected blocks was obtained from the respective village livestock inspectors and accordingly six villages viz., Apalgre, Balachanda, Balanggre, Adugre, Godalgre and Bainapara were selected for the study. Forty six indigenous practices under dairy management were collected from the elderly farm women belonging to West Garo Hills for determining the rationality.

Rationality of the collected indigenous practices was determined based on judges' opinion. Accordingly, forty indigenous dairy management practices were found to be rational and six indigenous practices were found to be irrational. Data were collected from 120 tribal farm women identified based on simple random sampling method. The responses on adoption of forty rational indigenous dairy practices were sought under two categories viz., adopted and not adopted. Simple percentage was used for interpretation of results. A well structured interview schedule was used for collection of data from the respondents.

\section{FINDINGS AND DISCUSSION}

In order to have an in depth idea about the adoption of practices, practice wise adoption of indigenous dairy management practices was analysed and the results are presented in Table1.

\section{Selection of Breed and Feeding}

It is noted from the table that 100 per cent of the respondents had adopted the practices viz., feeding dry roughages such as straw and hay to calving cows 
and feeding all types of fodder $(100.00 \%$ under each).This was followed by giving fresh water $(75.00 \%)$ and selection of indigenous breed $(79.17 \%)$. The respondents believed that feeding dry roughages and feeding fodder fulfilled the nutrient and mineral requirement of the animals. Similar finding on feeding dry roughages was reported by Bohra $\&$ Samajdar (2015).

Table1.

Practice-wise Adoption of Indigenous Dairy Management Practices

$(n=120)$

\begin{tabular}{|c|c|c|c|c|c|}
\hline \multirow{2}{*}{$\begin{array}{l}\text { S1. } \\
\text { No. }\end{array}$} & \multirow[b]{2}{*}{ Indigenous practices } & \multicolumn{2}{|c|}{ Adopted } & \multicolumn{2}{|c|}{ Not Adopted } \\
\hline & & Number & $\begin{array}{c}\text { Per } \\
\text { centage }\end{array}$ & Number & Percentage \\
\hline $\mathbf{I}$ & Selection of Breed and $F$ & ding & & & \\
\hline 1. & $\begin{array}{l}\text { Selection of indigenous } \\
\text { breed }\end{array}$ & 95 & 79.17 & 25 & 20.83 \\
\hline 2. & $\begin{array}{l}\text { Feeding dry roughages } \\
\text { such as straw and hay to } \\
\text { calving cows }\end{array}$ & 120 & 100.00 & - & - \\
\hline 3. & $\begin{array}{l}\text { Feeding all types of } \\
\text { fodder to cows }\end{array}$ & 120 & 100.00 & - & - \\
\hline 4. & $\begin{array}{l}\text { Giving fresh drinking } \\
\text { water to the cattle }\end{array}$ & 90 & 75.00 & 30 & 25.00 \\
\hline & Mean Percentage & - & 88.54 & - & 11.46 \\
\hline II & Milking Techniques & & & & \\
\hline 1. & $\begin{array}{l}\text { Washing the animals and } \\
\text { udder properly before } \\
\text { every milking }\end{array}$ & 65 & 54.17 & 55 & 45.83 \\
\hline 2. & $\begin{array}{l}\text { Full hand method of } \\
\text { milking }\end{array}$ & 120 & 100.00 & - & - \\
\hline 3. & $\begin{array}{l}\text { Tying feet and feeding } \\
\text { fodder during milking to } \\
\text { enhance work without } \\
\text { disturbance }\end{array}$ & 120 & 100.00 & - & - \\
\hline
\end{tabular}




\begin{tabular}{|c|c|c|c|c|c|}
\hline \multirow{2}{*}{$\begin{array}{l}\text { S1. } \\
\text { No. }\end{array}$} & \multirow[b]{2}{*}{ Indigenous practices } & \multicolumn{2}{|c|}{ Adopted } & \multicolumn{2}{|c|}{ Not Adopted } \\
\hline & & Number & $\begin{array}{c}\text { Per } \\
\text { centage }\end{array}$ & Number & Percentage \\
\hline 4. & $\begin{array}{l}\text { Maintaining } 8 \text { to } 12 \\
\text { hours of milking interval }\end{array}$ & 89 & 74.17 & 31 & 25.83 \\
\hline 5. & $\begin{array}{l}\text { Keeping bamboo leaves } \\
\text { submerged in milk to } \\
\text { preserve good quality of } \\
\text { milk }\end{array}$ & 49 & 40.83 & 71 & 59.17 \\
\hline & Mean Percentage & - & 73.83 & - & 26.17 \\
\hline III & \multicolumn{5}{|c|}{ Care and Management of Dry and Pregnant Cows } \\
\hline 1. & $\begin{array}{l}\text { Isolation of pregnant } \\
\text { cows from the rest }\end{array}$ & 120 & 100.00 & - & - \\
\hline 2. & $\begin{array}{l}\text { Stopping milking } 50 \text { to } \\
60 \text { days before expected } \\
\text { date of calving }\end{array}$ & 93 & 77.50 & 27 & 22.50 \\
\hline 3. & $\begin{array}{l}\text { Feeding roughages to } \\
\text { pregnant cows }\end{array}$ & 120 & 100.00 & - & - \\
\hline & Mean Percentage & - & 92.50 & - & 7.50 \\
\hline IV & \multicolumn{5}{|c|}{ Care during and after Calving } \\
\hline 1. & $\begin{array}{l}\text { Feeding colostrum to the } \\
\text { new-born calves within } \\
30 \text { minutes of calving }\end{array}$ & 120 & 100.00 & - & - \\
\hline 2. & $\begin{array}{l}\text { Applying turmeric paste } \\
\text { to the naval cord of the } \\
\text { new born calves as an } \\
\text { antiseptic agent }\end{array}$ & 120 & 100.00 & - & - \\
\hline 3. & $\begin{array}{l}\text { Within } 2 \text { hours after } \\
\text { delivery, jackfruit leaves } \\
\text { and rice bran with salt is } \\
\text { fed to the cow to induce } \\
\text { high milk secretion }\end{array}$ & 85 & 70.83 & 35 & 29.17 \\
\hline 4. & $\begin{array}{l}\text { Feeding rice bran with } \\
\text { salt to increase milk }\end{array}$ & 86 & 71.67 & 34 & 28.33 \\
\hline
\end{tabular}


Journal of Extension Education

\begin{tabular}{|c|c|c|c|c|c|}
\hline \multirow{2}{*}{$\begin{array}{l}\text { S1. } \\
\text { No. }\end{array}$} & \multirow{2}{*}{ Indigenous practices } & \multicolumn{2}{|c|}{ Adopted } & \multicolumn{2}{|c|}{ Not Adopted } \\
\hline & & Number & $\begin{array}{c}\text { Per } \\
\text { centage }\end{array}$ & Number & Percentage \\
\hline & Mean Percentage & - & 85.62 & - & 14.38 \\
\hline $\mathbf{v}$ & Treatment of Ailments & & & & \\
\hline 1. & $\begin{array}{l}\text { Local sword is heated } \\
\text { and pressed against the } \\
\text { teeth for toothache }\end{array}$ & 88 & 73.33 & 32 & 26.67 \\
\hline 2. & $\begin{array}{l}\text { Smearing neem leaf paste } \\
\text { on the affected parts to } \\
\text { control foot and mouth } \\
\text { disease }\end{array}$ & 89 & 74.17 & 31 & 25.83 \\
\hline 3. & $\begin{array}{l}\text { Making animals walk on } \\
\text { the mud to control foot } \\
\text { and mouth disease }\end{array}$ & 120 & 100 & - & - \\
\hline 4. & $\begin{array}{l}\text { Feeding country plantain } \\
\text { and little amount } \\
\text { of cumin seeds for } \\
\text { gastroenteritis problem }\end{array}$ & 88 & 73.33 & 32 & 26.67 \\
\hline 5. & $\begin{array}{l}\text { The leaves, flowers and } \\
\text { bark of the neem tree are } \\
\text { ground well and fed to } \\
\text { the cows for deworming }\end{array}$ & 76 & 63.33 & 44 & 36.67 \\
\hline 6. & $\begin{array}{l}\text { To control tympany, } \\
\text { water mixed with salt is } \\
\text { given }\end{array}$ & 91 & 75.84 & 29 & 24.16 \\
\hline 7. & $\begin{array}{l}\text { For dropping of placenta, } \\
\text { additional quantity of } \\
\text { bamboo leaves are fed to } \\
\text { the animals }\end{array}$ & 88 & 73.33 & 32 & 26.67 \\
\hline 8. & $\begin{array}{l}\text { Cactus (Carnegiea } \\
\text { giganta) fluid is applied } \\
\text { on the eyelids for eye } \\
\text { disease }\end{array}$ & 76 & 63.33 & 44 & 36.67 \\
\hline
\end{tabular}




\begin{tabular}{|c|c|c|c|c|c|}
\hline \multirow{2}{*}{$\begin{array}{l}\text { S1. } \\
\text { No. }\end{array}$} & \multirow{2}{*}{ Indigenous practices } & \multicolumn{2}{|c|}{ Adopted } & \multicolumn{2}{|c|}{ Not Adopted } \\
\hline & & Number & $\begin{array}{c}\text { Per } \\
\text { centage }\end{array}$ & Number & Percentage \\
\hline 9. & $\begin{array}{l}\text { Salt added with banana } \\
\text { leaves are fed to control } \\
\text { parasites }\end{array}$ & 71 & 59.17 & 49 & 40.83 \\
\hline 10. & $\begin{array}{l}\text { Banana stem juice for } \\
\text { treating all types of } \\
\text { stomach disorders }\end{array}$ & 85 & 70.83 & 35 & 29.17 \\
\hline 11. & $\begin{array}{l}\text { Using bamboo leaves for } \\
\text { treatment of diarrhoea }\end{array}$ & 84 & 70.00 & 36 & 30.00 \\
\hline 12. & $\begin{array}{l}\text { Feeding rice husk } \\
\text { with banana to control } \\
\text { diarrhoea }\end{array}$ & 95 & 79.17 & 25 & 20.83 \\
\hline 13. & $\begin{array}{l}\text { Feeding tamarind leaves } \\
\text { and mustard seeds } \\
\text { to control bleeding } \\
\text { dysentery }\end{array}$ & 59 & 49.17 & 61 & 50.83 \\
\hline 14. & $\begin{array}{l}\text { Feeding of arjun bark } \\
\text { (Terminalia arjuna) and } \\
\text { black pepper (Piper } \\
\text { nigrum) to control loose } \\
\text { motion }\end{array}$ & 80 & 66.67 & 40 & 33.33 \\
\hline 15. & $\begin{array}{l}\text { Feeding tea liquid in case } \\
\text { of blood in urine }\end{array}$ & 46 & 38.33 & 74 & 61.67 \\
\hline 16. & $\begin{array}{l}\text { Treating animals with } \\
\text { turmeric against bloat }\end{array}$ & 95 & 79.17 & 25 & 20.83 \\
\hline 17. & $\begin{array}{l}\text { Treating open wounds } \\
\text { with lime, garlic and } \\
\text { turmeric }\end{array}$ & 70 & 58.33 & 50 & 41.67 \\
\hline 18. & $\begin{array}{l}\text { Applying warm coconut } \\
\text { oil mixed with garlic } \\
\text { extract to open wounds }\end{array}$ & 89 & 74.17 & 31 & 25.83 \\
\hline
\end{tabular}


Journal of Extension Education

\begin{tabular}{|c|c|c|c|c|c|}
\hline \multirow{2}{*}{$\begin{array}{l}\text { S1. } \\
\text { No. }\end{array}$} & \multirow[b]{2}{*}{ Indigenous practices } & \multicolumn{2}{|c|}{ Adopted } & \multicolumn{2}{|c|}{ Not Adopted } \\
\hline & & Number & $\begin{array}{c}\text { Per } \\
\text { centage }\end{array}$ & Number & Percentage \\
\hline 19. & $\begin{array}{l}\text { Treating the wounds of } \\
\text { udder with neem leaf } \\
\text { paste }\end{array}$ & 78 & 65.00 & 42 & 35.00 \\
\hline 20. & $\begin{array}{l}\text { Application of ghee in } \\
\text { case of cracking of udder }\end{array}$ & 85 & 70.83 & 35 & 29.17 \\
\hline 21. & $\begin{array}{l}\text { Control of intestinal } \\
\text { parasites with pineapple } \\
\text { leaves }\end{array}$ & 75 & 62.50 & 45 & 37.50 \\
\hline 22. & $\begin{array}{l}\text { Feeding sugarcane to the } \\
\text { animals suffering from } \\
\text { jaundice }\end{array}$ & 55 & 45.83 & 65 & 54.17 \\
\hline 23. & $\begin{array}{l}\text { Applying Doorva } \\
\text { (Cynodon dactylon Linn.) } \\
\text { leaves paste for bleeding } \\
\text { from any injury }\end{array}$ & 57 & 47.50 & 63 & 52.50 \\
\hline 24. & $\begin{array}{l}\text { Applying marigold } \\
\text { (Calendula officinalis) } \\
\text { paste in case of bleeding } \\
\text { from any injury }\end{array}$ & 45 & 37.50 & 75 & 62.50 \\
\hline 25. & $\begin{array}{l}\text { To prevent tick, lice and } \\
\text { bovine flies, powder of } \\
\text { calamus (Acorus calamus) } \\
\text { is mixed with the leaf } \\
\text { extract of Tulsi (Ocimum } \\
\text { sanctum) is smeared on } \\
\text { the body }\end{array}$ & 70 & 58.33 & 50 & 41.67 \\
\hline & Mean Percentage & - & 65.17 & - & 34.83 \\
\hline
\end{tabular}




\section{Milking Technique}

Hundred per cent of the respondents had adopted full hand method of milking, Tying feet and feeding fodder during milking to enhance work without disturbance. This was followed by other practices viz., maintaining 8 to 12 hours of milking interval (74.17\%) and washing the animals and udder properly before every milking (54.17\%), while only about two- fifth of the respondents $(40.83 \%)$ kept bamboo leaves submerged in milk to preserve the quality of milk. Full hand method of milking is perceived as easy and comfortable method by the farm women and hence all of them might have fully adopted. Similar finding on washing the animals and udder properly before every milking was reported by Gnanasekar \& John Christy (2013).

\section{Care and Management of Dry and Pregnant Cows}

Hundred per cent of the respondents had isolated pregnant cows from the rest and fed dry roughages in the shed to pregnant cows. Stopping milking 50 to 60 days before calving was followed by 77.50 per cent of the respondents. Majority of the respondents expressed that pregnant cows cannot be taken out to the field as it needed extra care. Hence, they might have fed dry roughages in the shed itself. The finding on isolation of pregnant cows is in line with the findings of Saha (2014).

\section{Care during and after Calving}

It could be further observed that 100 per cent of the respondents had fed colostrum to the new born calves within 30 minutes of calving and applied turmeric paste to the naval cord of the new born calves as an antiseptic agent. The other practices adopted by them to a greater extent were feeding rice bran with salt to increase milk (71.67\%) and feeding jackfruit leaves and rice bran with salt within 2 hours after delivery to induce high milk secretion (70.83\%).

All the respondents would have fed colostrum to the new-born calves to ensure the good health of the calves and might have applied turmeric paste to the naval cord of the new born calves as they perceived it to be an effective antiseptic agent. Similar finding on feeding colostrum was reported by Bohra \& Samajdar (2015).

\section{Treatment of Ailments}

It is observed from the table that 100 per cent of the respondents made animals walk on the mud to control foot and mouth disease. Adoption ranged from 80.00 to 70.00 per cent for the practices viz., feeding rice husk with banana to control diarrhoea and treating cows with turmeric against bloat (79.17\%), provided water mixed with salt to control tympany (75.84\%), smeared neem leaf paste on the affected parts to control foot and mouth disease and applied warm coconut oil mixed with garlic extract to open 
wounds $(74.17 \%)$, pressed heated local sword against the teeth for toothache, fed country plantain and little amount of cumin seeds for the gastroenteritis problem, additional quantity of bamboo leaves was fed to the animals for dropping of placenta (73.33\%), banana stem juice was provided for all types of stomach disorders, bamboo leaves were given for treatment of diarrhoea and ghee was applied for cracking of udder (70.83 $\%)$. Making animals walk on the mud to control foot and mouth disease was perceived as highly effective and easy method of treating the foot and mouth disease. Turmeric was utilized to a greater extent by majority of the respondents to control bloat as it is perceived to be very effective. Similarly, water mixed with salt was mentioned as very effective to control tympany compared to other methods. The finding on treating wounds of udder is reported by Saha et al. (2010). Treating open wounds with lime, garlic and turmeric had been also reported by Mishra (2013).

\section{CONCLUSION}

Within the tribal populations, women traditionally have greater responsibility both in agriculture and livestock sectors, which drives them to interact more with the surroundings. As observed adoption of indigenous dairy management practices results with eco-friendly environment and is necessary to make promotional efforts for the preservation and spread of these practices.
The findings of the study reveal that majority of the tribal farm women had adopted the indigenous dairy management practices to a higher extent. This shows the conviction of farm women in the adoption of indigenous dairy management practices. Therefore extension workers should identify and include them in the technology transmission process for effectiveness.

\section{REFERENCES}

Anonymous. (2014). Work Participation of Tribal Women in India - A Development Perspective, JOSR Journal of Humanities and Social Service, 19 (12), 35-38.

Bohra, Sagarika \& Samajdar, T. (2015). Dairy Farming. Krishi Vigyan Kendra, ICAR Research Centre for North Eastern Hill region, Tura District, West Garo Hills.

Gnanasekar, R., \& John Christy, R. (2013). Knowledge Level of Livestock Keepers on Clinical Mastitis Control Measures in Villupuram District of Tamil Nadu, Journal of Extension Education, 25(1):4999.

Mishra,Dibakar. (2013).CattleWoundand Ethno-veterinary Medicine - A Study in Polasara Block, Ganjam District, Orissa, Indian Research Journal Extension Education, 12(1):62-65.

Mooventhan, P. Kadian, K., Senthilkumar, R., \& Karpagam, C. (2016). Economic profiling of Tribal Dairy Framers in Northern Hills Zone of Chattisgarh. 
Journal of Extension Education, 27(3)

Saha, A. (2014). Indigenous Breeding and Management Practices of Dairy Animals-A Study on Documentation, Scholars Journal of Agriculture and Veterinary Sciences, 1(4A), 216-221.

Saha, A., Mukhopadhya, S.B. \& Das
Gupta, D., (2010). Inventory of Indigenous Healthcare, Indian Journal of Traditional Knowledge, 9(2),326332.

Serote. (2001). The Role of Indigenous Knowledge in Environmental Health Risk, Science Education, 85(1),6-34. 